\title{
MODEL PEMBELAJARAN REMEDIAL MEMBACA PERMULAAN DENGAN PENDEKATAN PENGALAMAN BERBAHASA PADA SISWA SEKOLAH DASAR
}

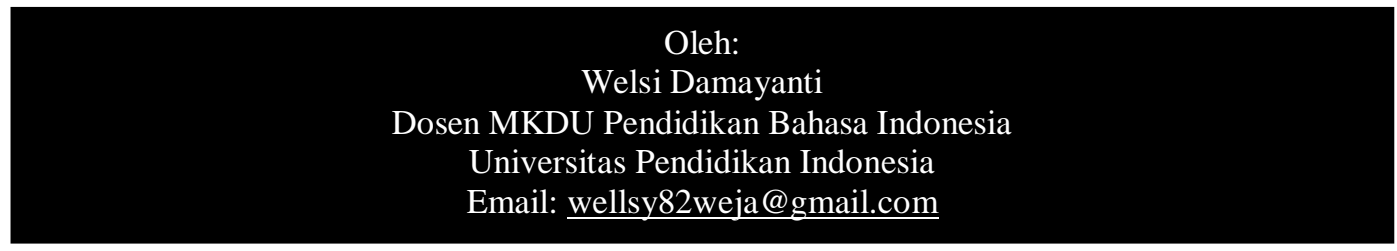

Abstract. In life, reading skill is conditio sine qua non. Thus, reading skill is an essential need to keep updated. In the world of education, reading activities can be considered as the heart of education. Through reading, everyo,ne can follow new developments that occur in life. If associated with education program in school, reading plays a very important role. Reading skill is the main factor that will determine the learning achievement. At elementary level, research reported that students' reading skill was far from expectation. Research by The International Association for The Evaluation of Educational Achievement (1997) found that the reading skill of elementary school students in Indonesia only ranked the $31^{\text {st }}$. Therefore, to assist children who have difficulty in reading and to develop their reading skill, teacher can use Early Reading Remedial Instruction Model with LEA (Language Experience Approach).

Keywords: remedial instruction model, reading skill, early reading, pendekatan pengalaman berbahasa

\begin{abstract}
Abstrak, Kemampuan membaca dalam kehidupan merupakan conditio sine qua non. Oleh karena itu, kemampuan membaca menjadi kebutuhan yang sangat penting jika tidak ingin ketinggalan zaman. Dalam dunia pendidikan, kegiatan membaca dapat dipandang sebagai jantungnya pendidikan. Melalui kegiatan membaca, setiap orang dapat mengikuti perkembangan baru yang terjadi dalam kehidupan. Jika dikaitkan dengan program pendidikan di sekolah, membaca memegang peranan yang sangat penting. Melalui kegiatan membaca, setiap orang dapat mengikuti perkembangan baru yang terjadi dalam kehidupan. Jika dikaitkan dengan program pendidikan di sekolah, membaca memegang peranan yang sangat penting. Kemampuan membaca merupakan faktor utama yang ikut menentukan prestasi belajar. Pada jenjang Sekolah Dasar (SD) diperoleh laporan hasil penelitian mengenai kemampuan membaca yang masih jauh dari harapan. Penelitian The International Association for The Evaluation of Educational Achievement (1997), melaporkan bahwa kemampuan membaca murid SD di Indonesia hanya menduduki peringkat ke-31. Oleh karena itu, perkembangan kemampuan membaca anak yang mengalami kesulitan membaca bisa menggunakan Model Pembelajaran Remedial Membaca Permulaan dengan Pendekatan LEA (Language Experience Approach)/Pendekatan Pengalaman Berbahasa.
\end{abstract}

Kata kunci: model pembelajaran remedial, membaca, membaca permulaan, pendekatan LEA

\section{A. PENDAHULUAN}

Undang-undang No. 20 Tahun 2003

Pasal 3 tentang Sistem Pendidikan

Nasional merumuskan tujuan Pendidikan
Nasional yang berfungsi "mengembangkan kemampuan dan membentuk watak serta peradaban bangsa yang bermartabat dalam rangka mencerdaskan kehidupan bangsa, 
bertujuan untuk berkembangnya potensi peserta didik agar menjadi manusia yang beriman dan bertakwa kepada Tuhan Yang Maha Esa, berakhlak mulia, sehat, berilmu, cakap, kreatif, mandiri, dan menjadi warga negara yang demokratis serta bertanggung jawab". Untuk mencapai tujuan itu, sekolah dasar sebagai sebuah lembaga formal dalam memberikan layanan pendidikan berperan mendorong tumbuh kembang anak, termasuk meningkatkan keterampilan berbahasa, khususnya dalam membaca dan menulis permulaan.

Berbagai pernyataan yang

menjelaskan betapa pentingnya kemampuan membaca telah diungkapkan oleh banyak pakar. Diantaranya Rusyana (1984: 190) berpendapat bahwa kemampuan membaca sangat penting untuk pemeliharaan dan pengembangan kehidupan suatu masyarakat, baik perseorangan maupun sebagai bangsa, agar suatu masyarakat dapat bertahan di muka bumi.

Kemampuan membaca dalam kehidupan merupakan conditio sine qua non. Oleh karena itu, kemampuan membaca menjadi kebutuhan yang sangat vital jika tidak ingin ketinggalan zaman. Dalam dunia pendidikan, kegiatan membaca dapat dipandang sebagai jantungnya pendidikan. Melalui kegiatan membaca, setiap orang dapat mengikuti perkembangan baru yang terjadi dalam kehidupan. Jika dikaitkan dengan program pendidikan di sekolah, membaca memegang peranan yang sangat penting. Menurut Tarigan (1984: 28) banyaknya kegiatan membaca yang dilakukan seseorang akan mewarnai kemampuan membacanya.

Pada jenjang Sekolah Dasar (SD) diperoleh laporan hasil penelitian mengenai kemampuan membaca yang masih jauh dari harapan. Penelitian The International Association for The Evaluation of Educational Achievement (1997), melaporkan bahwa kemampuan membaca murid SD di Indonesia hanya menduduki peringkat ke-31, yaitu peringkat nomor dua dari peringkat terakhir di dunia, satu tingkat saja di atas Venezuela (Damaianti, 2001: 2). Hasil penelitian itu sangat memprihatinkan dan merupakan tantangan bagi para pendidik untuk memperbaiki keadaan tersebut.

Mengenalkan anak pada huruf adalah suatu dasar pendidikan umum yang sangat penting. Dengan pengetahuan huruf terbukalah bagi anak didik segenap cabang kebudayaan bangsa, bahkan kebudayaan umat manusia di seluruh dunia. Hasil usaha manusia tersimpan dalam buku-buku yang pada hakekatnya hanya berisi kelompok-kelompok huruf. Dengan mengenal huruf, anak mampu menggali ilmu dari segala bidang. Menurut Nurjanah (1999: 4), sampai saat ini di Indonesia 
dikenal ada enam metode pengajaran membaca permulaan, yaitu 1) metode abjad/alfabet, 2) metode bunyi, 3) metode suku kata, 4) metode kata, 5) metode kalimat/global, dan 6) metode struktural analitik sintesis/SAS.

Dari hasil wawancara peneliti pada bulan Januari 2014 dengan guru kelas I dan II SD Bojongloa Cibaduyut, pengajaran membaca permulaan di SD tersebut menggunakan metode Suku Kata. Hal tersebut dilakukan dengan alasan metode tersebut adalah metode yang paling efektif, sedangkan metode yang lain terutama Metode SAS terlalu sulit diterapkan karena prosedurnya yang berbelit-belit.

Pendekatan lain dalam pengajaran membaca permulaan yang telah dikembangkan di luar negeri adalah pendekatan LEA (Language Experience Approach) atau Pendekatan Pengalaman Berbahasa. Pendekatan Pengalaman Berbahasa dalam pengajaran membaca permulaan merupakan suatu pendekatan yang memanfaatkan kata-kata si anak atau kalimat-kalimat lisan anak yang kemudian diubah dalam bentuk tulisan sebagai materi pengajaran membaca. Dalam pendekatan ini, membaca menduduki tempat yang sama pentingnya dengan keterampilanketerampilan berbahasa lainnya untuk membentuk dasar kemampuan berkomunikasi. Jadi membaca dianggap sebagai satu bagian dari proses berkomunikasi.

Untuk mengetahui penerapan Pendekatan Pengalaman Berbahasa dalam meremedial anak-anak yang mengalami kesulitan membaca perlu dilakukan penelitian tersendiri. Setelah diketahui tingkat keberhasilannya, model ini dapat dijadikan model pengajaran remedial membaca permulaan. Penelitian semacam ini sangat penting karena dengan demikian akan diperoleh sejumlah informasi yang sangat membantu dalam memperbaiki pengajaran membaca permulaan di Sekolah Dasar serta dapat dipergunakan untuk meremedial anak didik yang mengalami kesulitan membaca permulaan.

Dengan pertimbangan-pertimbangan itulah, peneliti terdorong untuk melakukan penelitian tentang perkembangan kemampuan membaca anak yang mengalami kesulitan membaca menggunakan Model Pembelajaran Remedial Membaca Permulaan dengan Pendekatan LEA (Language Experience Approach)/Pendekatan Pengalaman Berbahasa.

\section{B. HASIL DAN PEMBAHASAN}

\section{Membaca}

\section{a. Pengertian Membaca}

Pengertian membaca adalah 1) melihat serta memahami isi dari apa yang tertulis dengan melisankan atau 
Edutech, Tahun 13, Vol.1, No.3, Oktober 2014

hanya dalam hati; 2) mengeja atau melafalkan apa yang tertulis; 3) mengucapkan; 4) meramalkan, mengetahui; 5) menduga, memperhitungkan, memahami (Depdikbud, 1996: 345). Pengertian tersebut menunjukkan bahwa membaca merupakan suatu proses mengeja, melafalkan, dan memaknai segala sesuatu yang tertulis, baik secara bersuara maupun dalam hati.

Menurut Plato dalam Harjasujana dan Damaianti (2003: 27) membaca merupakan suatu kegiatan membedakan huruf dengan mata dan telinga agar tidak dibingungkan oleh posisinya nanti jika tampak dalam bentuk tulisan atau terdengar dalam bentuk tulisan.

\section{b. Membaca Permulaan}

Keterampilan membaca permulaan merupakan salah satu kunci keberhasilan karena dengan itu para siswa akan mampu menggali informasi dari berbagai sumber tertulis. Membaca permulaan adalah dasar bagi kegiatan membaca lanjutan. Menurut Devine (1989:

7) mengatakan bahwa membaca permulaan dapat didefenisikan sebagai pemerolehan tiga benang pengetahuan anak didik yang berhubungan dengan fungsional, formal, dan konvensional.

1) Fungsional

Fungsional berkenaan dengan fungsi bahan cetak. Anak didik mula-mula menjadi sadar terhadap kata-kata yang dicetak yang menunjukkan makna bahasa sehingga mereka bisa menemukan kata dan konsep itu berada dalam bentuk cetak dan dalam bahasa lisan.

2) Formal

Formal berkenaan dengan bentuk dan struktur bahan cetak. Anak didik mencoba mengenali bahan cetak atau mengejanya sehingga mereka menyadari bahwa huruf-huruf memiliki bentuk-bentuk yang berbeda yang dapat dihubungkan dengan bunyi-bunyi kata yang dikenalnya dan mereka dapat menjodohkan bunyi huruf awal dalam kata tersebut.

3) Konvensional 
Edutech, Tahun 13, Vol.1, No.3, Oktober 2014

Konvensional berkenaan dengan konvensi bahan cetak. Anak didik memperoleh berbagai informasi tentang konvensi bahan cetak dan istilahistilah yang berhubungan dengan membaca. Misalnya mereka menjadi paham tentang istilahistilah "lihat kalimat pertama!", "temukan kata pada awal paragraf!", atau mereka mengetahui tentang kaidah seperti membaca dari kiri ke kanan.

Dalam buku Petunjuk Teknis Pengajaran Membaca Permulaan di Sekolah Dasar diterangkan bahwa membaca permulaan diberikan di kelas I dan II SD. Sesuai dengan kemampuan dan perkembangan kejiwaan anak, pengajaran membaca permulaan di kelas I bertujuan agar anak terampil membaca, sedangkan di kelas II di samping agar anak terampil membaca juga mampu mengembangkan pengetahuan bahasa dan keterampilan berbahasa.
Tujuan

pengajaran membaca permulaan adalah mengetahui huruf dan terampil mengubah huruf menjadi suara. Menurut Sudjana (1988: 19) mengemukakan tentang tujuan pengajaran membaca permulaan adalah sebagai berikut.

1) Mengenalkan pada para anak didik huruf-huruf dalam abjad, sebagai tanda suara atau tanda bunyi.

2) Melatih keterampilan anak didik untuk mengubah huruf-huruf dalam kata menjadi suara.

3) Mengetahui huruf-huruf dalam abjad dan melatih keterampilan anak didik untuk menyuarakannya dan dalam waktu singkat dapat mempraktekkannya dalam membaca lanjut.

Dalam penelitian ini karena merupakan kegiatan membaca permulaan, maka aspek dalam proses membaca yang ingin dicapai adalah keterampilan yang bersifat mekanis (mechanical skills) yang meliputi pengenalan huruf, pengenalan unsur-unsur 
Edutech, Tahun 13, Vol.1, No.3, Oktober 2014

linguistik, pengenalan

Menurut Howard dalam

hubungan korespodensi pola

Erhamwilda

(1997:36-38)

ejaan dan bunyi, dan kecepatan

mengungkapkan tiga aspek membaca bertaraf lambat. Aspek proses membaca yang lebih tinggi yang merupakan keterampilan yang bersifat pemahaman bukan menjadi aspek kajian penelitian ini.

\section{c. Faktor-faktor Penyebab \\ Kesulitan \\ Membaca \\ Permulaan}

Pada awal belajar
membaca anak belajar mengenal beberapa kata dan mulai mengenal phonic yang sama dan elemen-elemen struktural dalam kata-kata yang lain. Anak yang belajar membaca tidak hanya membuat perpaduan antara bentuk tulisan dengan bentuk pengucapan tetapi anak mesti mengerti grammar and syntax sehingga frase dan kalimat membuat pengertian dan memberi makna. Anak mesti dapat mengikuti suatu perkembangan pemikiran dan informasi, menggambarkan kesimpulan, mengingat kembali informasi, memperkirakan validitasnya, kualitas keindahannya, dan selanjutnya.

penyebab kesulitan membaca, yaitu 1) fisik, 2) pendidikan, dan 3) psikologis.

1) Aspek fisik

Adapun yang termasuk ke dalam aspek ini adalah pendengaran, masalah penglihatan, faktor-faktor psikologis dalam dirinya, terutama sistern syaraf otak yang defektif dan disfungsi. Beberapa gangguan fisik seperti kerusakan otak, ketidakberfungsian saraf-saraf otak, gangguan persepsi, keterbelakangan mental, cerebral palsy, aphasia, dan disleksia telah dipelajari bagaimana hubungannya dengan ketidakmampuan membaca dan bahasa lainnya.

2) Aspek pendidikan

Adapun yang dikatakan aspek pendidikan adalah kegiatan yang dilakukan sekolah, guru, petugas administrasi, ahli kurikulum, orang tua, dan masyarakat dalam pendidikan. Misalnya: Bagaimana pribadi tertentu secara langsung di dalam kelas 
Edutech, Tahun 13, Vol.1, No.3, Oktober 2014

mempengaruhi motivasi,

kehendak, atau pemahaman anak?; Bagaimana buku-buku dan materi pelajaran digunakan dalam kurikulum, sistem evaluasi, dan penyusunan pengelompokkan mempengaruhi perasaan anak?

3) Aspek psikologis

Adapun yang termasuk aspek ini adalah emosi seperti ketakutan, kecemasan kepercayaan, cinta, dan benci yang terpendam di dalam diri yang mempengaruhi manusia dengan tidak diduga-duga. Secara nyata sulit mengidentifikasi pengaruh emosi dan sulit mengatakan misalnya berapa banyak kecemasan dan ketakutan mungkin mengganggu tugastugas. Emosi berpengaruh secara tidak langsung pada setiap tingkah laku individu.

Persepsi merupakan salah satu yang berpengaruh pada kesulitan dalam belajar membaca. Beberapa ahli seperti Orton, Gillingham, dan Fernald yang dikutip Howard dalam Erhamwilda $\quad$ (1997:38-40) memasukkan kegiatan diagnostik dan mengoreksi kegiatan dalam persepsi dalam upaya memberikan bantuan bagi anak yang mengalami kesulitan membaca.

Mereka memandang persepsi secara luas sebagai akar tingkah laku individu. Persepsi didefinisikan mengenai setiap orang dan mengenai seluruh kepribadian individu. Persepsi berkaitan dengan bentuk, kondisi, warna, tekstur dan bunyi. Persepsi dalam arti singkat bukan sekedar kemampuan anak, misalnya membedakan 'b' dan 'p' secara visual atau secara oral, atau besar dan kecil, dan sebagainya tapi lebih dari itu. Proses perseptual meliputi juga proses kognitif, interpretasi konseptual dari data seperti emosi dan afektif. Persepsi adalah keseluruhan, terpadu dan memadukan serta photographic.

Howard dalam Erhamwilda (1997:38-40) menyatakan bahwa akar dari masalah perseptual tertentu tidak hanya fisik atau gangguan psikis atau ketidakberfungsian, atau hanya kurikulum atau guru, dan materi itu sendiri, 
Edutech, Tahun 13, Vol.1, No.3, Oktober 2014

tetapi sifat simbolis dari semua tingkah laku manusia.

Sementara itu Guy L. Bond, Miles A. Tinker dan Barbara B. Watson, dalam Erhamwilda (1997:40) menjelaskan sebab-sebab kesulitan membaca yang hampir senada dengan pendapat di atas, yaitu:

1) Faktor-faktor fisik meliputi gangguan penglihatan, pendengaran, pengucapan, masalah kesehatan umumnya, gangguan yang berhubungan dengan kelenjar, syaraf, dan keterbatasan intelektual.

2) Faktor emosional, lingkungan dan faktor pendidikan

Pandangan lain tentang faktor yang mempengaruhi kesulitan membaca diungkapkan oleh J. Estill Alexander (1988) dalam Erhamwilda (1997:44) adalah adanya tiga faktor penting yang sating berinteraksi pada kegiatan membaca seseorang, yakni faktor afektif, kognitif, dan bahasa. Pada faktor afektif, ada beberapa aspek yakni konsep diri, kemandirian, penguasaan lingkungan, persepsi tentang realitas dan kecemasan.

Dari berbagai faktor di atas nampak bahwa kesulitan membaca dapat disebabkan oleh faktor fisik, penyesuaian pribadi sosial, kognitif, afektif, sosial, budaya, bahasa, dan faktor-faktor lingkungan.

Dari hasil wawancara dan observasi yang telah dilakukan peneliti terhadap subjek penelitian, faktor yang menyebabkan kesulitan membaca adalah dari diri siswa (faktor internal) dan dari Iuar (faktor eksternal). Adapun faktor internal yang menyebabkan kesulitan membaca keempat subjek penelitian adalah kurangnya motivasi belajar (kurangnya kemauan dan keinginan untuk belajar) dan kondisi emosional anak akibat adanya rasa kekecewaan dan frustasi atas kegagalan atau ketidakmampuan membacanya. Sedangkan faktor eksternalnya meliputi kurangnya perhatian dari orang tua, kondisi, suasana, sarana dan prasarana belajar di rumah yang kurang kondusif. 
Edutech, Tahun 13, Vol.1, No.3, Oktober 2014

2.Model Pembelajaran Remedial Membaca Permulaan

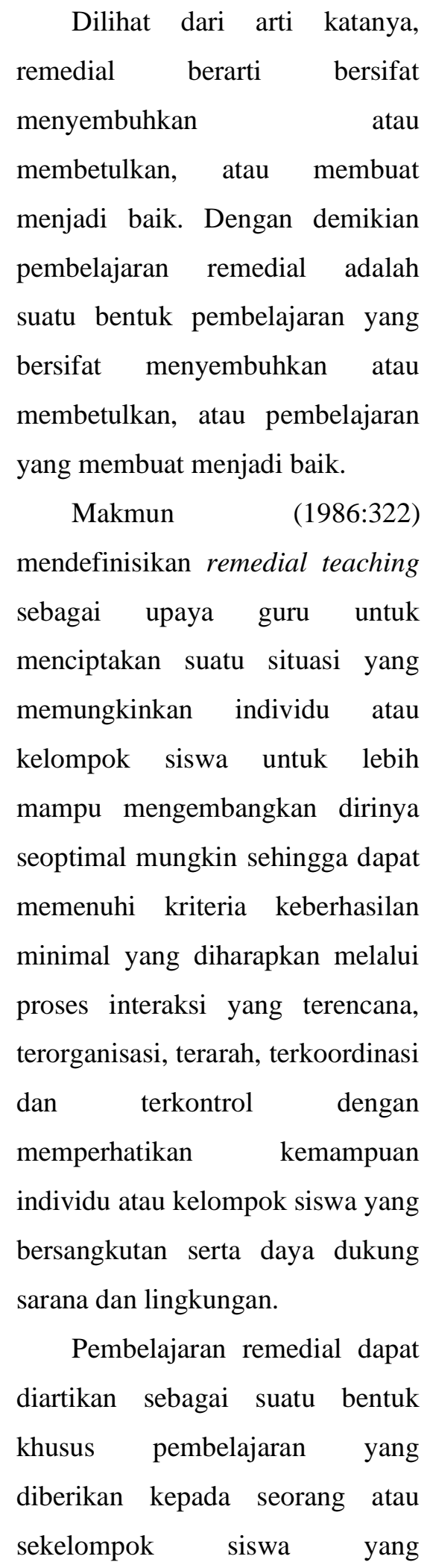

diperkirakan mengalami kesulitan belajar. Karena bentuknya yang khusus, maka pengajarannya disesuaikan dengan jenis dan sifat kesulitan belajar yang dihadapi murid. Proses bantuan lebih ditekankan pada usaha-usaha perbaikan cara belajar, cara mengajar, menyesuaikan materi pelajaran, penanggulangan hambatan-hambatan yang dihadapi.

Dari berbagai pengertian pembelajaran remedial di atas, apabila dikaitkan dengan pengertian model dan pengertian membaca permulaan maka dapat diambil benang merah bahwa model pembelajaran remedial membaca permulaan adalah suatu rencana atau pola yang digunakan oleh guru untuk menciptakan suatu situasi yang memungkinkan individu atau kelompok siswa untuk sadar terhadap kata-kata yang dicetak yang menunjukkan makna bahasa sehingga mereka bisa menemukan kata dan konsep itu berada dalam bentuk cetak dan dalam bahasa lisan, anak didik mencoba mengenali bahan cetak atau mengejanya sehingga mereka menyadari bahwa huruf-huruf memiliki bentuk-bentuk yang 
Edutech, Tahun 13, Vol.1, No.3, Oktober 2014

berbeda yang dapat dihubungkan dengan bunyi-bunyi kata yang dikenalnya dan mereka dapat menjodohkan bunyi huruf dengan bunyi awal dalam kata tersebut, anak didik mernperoleh berbagai informasi tentang konvensi bahan cetak dan istilah-istilah yang berhubungan dengan membaca, sehingga dapat memenuhi kriteria keberhasilan minimal yang diharapkan melalui proses interaksi yang terencana, terorganisasi, terarah, terkoordinasi dan terkontrol dengan memperhatikan kemampuan individu atau kelompok siswa yang bersangkutan serta daya dukung sarana dan lingkungan.

Jadi dalam pembelajaran remedial membaca permulaan ini yang disembuhkan, yang diperbaiki atau yang dibetulkan adalah keseluruhan proses belajar mengajar membaca yang meliputi cara belajar, metoda mengajar, materi pelajaran, alat belajar dan lingkungan yang turut serta mempengaruhi proses belajar mengajar membaca. Dengan pembelajaran remedial membaca permulaan diharapkan murid yang mengalami kesulitan membaca dapat keluar dari masalahnya dan meningkatkan prestasinya serta mencapai basil yang optimal sesuai dengan kemampuannya.

\section{a. Metode-metode Pengajaran Remedial Membaca Permulaan}

Setiap siswa yang diberikan pengajaran remedial memiliki tingkat kesulitan yang berbedabeda. Oleh karena itu, penanganan atau pengajaran remedial yang diberikan berbeda pula. Berdasarkan hal tersebut, ada beberapa model pengajaran remedial yang dapat dilakukan guna meremedial siswa (Harjanatawiyoga dan Baihagi, 1992:9), yaitu dengan 1) metode auditif, 2) metode perbandingan kata, 3) metode mengeja, dan 4) metode gabungan

1) Metode Auditif

Pengajaran remedial membaca dengan metode auditif dilakukan secara bertahap, yaitu:

- Tahap Kata Lembaga Pertama

Pada papan tulis dituliskan sebuah kata. Sebaiknya kata tersebut dipilih berdasarkan usulan anak. Anak diminta memperhatikan tulisan tersebut lalu membacanya sendiri sambil menyelusurinya pada 
Edutech, Tahun 13, Vol.1, No.3, Oktober 2014

papan tulis. Ini diulang

Anak membuat cerita beberapa kali sehingga anak sederhana dengan mengenal betul kata tersebut. Lama-lama penyelusuran huruf dapat dilakukan dengan pensil di udara sampai anak bisa menuliskannya sendiri tanpa melihat contoh. Dua atau lebih kata lain diperkenalkan pula dan dipelajari seperti kata yang pertama tadi. Kata-kata yang telah dikuasai anak disimpan dalam sebuah album kata.

- Tahap Membaca Kalimat

Setelah anak menguasai beberapa kata, di papan tulis dibuat sebuah atau dua buah kalimat dengan mempergunakan kata-kata tersebut. Kalimat-kalimat ini dibaca sendiri, ditulis, dan dibaca kembali. Kalimatkalimat yang sudah dikuasai lalu ditulis dengan huruf cetak pada lembaran-lembaran kertas dan dikumpulkan menjadi sebuah buku bacaan. Pembuatan berbagai kalimat terus dilakukan dengan menggunakan kata-kata yang relatif sedikit. Kata-kata baru diajarican seperti halnya kata yang pertama.

- Tahap Membaca Cerita

menggunakan kata-kata dan kalirnat-kalimat yang telah dipelajari. Jika diperlukan, kata-kata yang baru boleh dimasukkan. Selain dimasukkan dalam bacaan, kata-kata tersebut ditulis pula pada satu daftar terpisah. Di atas daftar diletakkan sebuah tutup (karton) yang mempunyai lubang sebesar sebuah kata Dengan menggeserkan tutup lubang tersebut kata-kata yang baru nampak pada lubang tadi. Anak meniru membaca kata baru tadi sambil menuliskannya tanpa melihat contoh.

- Tahap Membaca Rangkaian Kata

Setelah anak dapat membaca kata-kata yang telah diajarkan satu demi satu, ia juga mendapat latihan membaca rangkaian kata-kata tersebut. deretkan dua atau lebih kata-kata yang sudah dikenal dan suruh anak membaca deretan kata tersebut.

- Tahap Membaca Isi

Setelah anak berhasil dalam tahap sebelumnya, suruhlah anak membacanya lagi dengan tidak 
Edutech, Tahun 13, Vol.1, No.3, Oktober 2014

bersuara dan menceritakan isinya secara singkat.

\section{2) Metode Perbandingan Kata}

Metode ini dipergunakan untruk membantu anak yang kurang terlatih melihat perbedaan huruf yang satu dengan huruf yang lain. Misalnya ada anak yang mendapat kesulitan mengingat huruf t. Kita akan memberikan beberapa kata yang dimulai dengan huruf $t$, misalnya topi, tati, tali, dan sebagainya.

Anak diminta melakukan berbagai kegiatan mengenai kata-kata tersebut. Mula-mula membacanya, lalu menjiplaknya, membuat gambargambar topi, tali, tati. Mewarnai gambar-gambar tersebut, menggunting, dan menempelkannya pada kertas lain, dan sebagainya. Kegiatankegiatan ini dilakukan agar anak dapat membaca kata-kata tersebut tanpa bantuan orang lain.

Selanjutnya guru membuat beberapa kartu. Di dalamnya, guru menuliskan kalimatkalimat yang mempergunakan kata-kata tersebut serta sebuah gambar mengenai salah satu kata yang dimaksud. Tugas anak ialah menggarisi kata yang sesuai dengan gambar. Dengan demikian anak harus membandingkan kata-kata tersebut.

Pada kartu yang lain, kalimat-kalimat tersebut disusun dengan urutan yang lain. Gambarnya pun diganti.

3) Metode Mengeja

Metode ini menyerupai mengajar membaca permulaan yang menggunakan metode mengeja. Mula-mula anak berkenalan dengan sebuah huruf vokal, misalnya a. kemudian diperkenalkan dengan dua huruf konsonan, misalnya $\mathrm{n}$ dan $\mathrm{s}$. dengan mengenal ketiga huruf tersebut dapat disusunlah suku kata seperti an, as, na, dan sa.

Dengan berbagai cara, anak berlatih membedakan suku kata tersebut. Misalnya dengan menuliskan pada kartukartu yang terpisah, mengocoknya dan mengambil salah satu kartu, serta membaca tulisan kartu yang terambil, dan seterusnya.

Setelah langkah ini berhasil, anak berkenalan pula 
Edutech, Tahun 13, Vol.1, No.3, Oktober 2014

dengan konsonan-konsonan

\section{a. Pengertian \\ Pendekatan}

lain secara berangsur-angsur.

\section{Pengalaman Berbahasa}

Setiap huruf konsonan baru disambungkan dengan huruf vokal yang telah diajarkan sehingga membentuk suku kata-suku kata baru. Selanjutnya anak berlatih membedakan suku kata-suku kata baru dengan cara seperti tadi.

Tahap selanjutnya anak diperkenalkan dengan huruf vokal yang lain secara berangsur-angsur. Setiap huruf vokal harus dapat dibaca dalam deretannya dengan salah satu huruf konsonan. Setelah terbentuk beberapa suku kata, maka suku kata-suku kata ini disambungkan hingga menjadi kata dan kemudian menjadi kalimat secara bertahap.

\section{4) Metode Gabungan}

Huruf atau kata yang dipergunakan dalam metode ini adalah huruf atau kata yang menjadi kesukaran baca di anak. Oleh karena itu kita harus mengenal betul kesukaran anak yang akan kita remedial.

\section{Pendekatan \\ Pengalaman \\ Berbahasa} terbitan 1981 halaman 173, Language Experience Approach, yang dapat diterjemahkan secara bebas menjadi Pendekatan Pengalaman Berbahasa dijelaskan sebagai suatu pendekatan dalam belajar membaca di mana bahasa anak/sekelompok siswa itu sendiri atau kalimat-kalimat lisannya dituliskan dan digunakan sebagai materi pengajaran membaca, menulis, mengeja, berbicara dan menyimak. Dalam Kalimat aslinya seperti berikut:

"Language Experience Approach is an approach to learning to read in which the student"s or graoup"s own words or oral compositions are written down and used as materials of instruction for reading, writing and spelling, speaking and listening"

Pendekatan Pengalaman Berbahasa dikatakan sebagai pendekatan yang mengintegrasikan menyimak, berbicara, membaca dan menulis dengan mengggunakan berbagai materi 
Edutech, Tahun 13, Vol.1, No.3, Oktober 2014

dan aktivitas yang dikaitkan dengan dunia si anak itu sendiri. Jadi Language Experience Programme dijelaskan sebagai Integrates work in listening, speaking, reading and writing by using a variety of materials and activities relating to the child's own world.

Menurut berbagai sumber yang membahas mengenai Pendekatan Pengalaman Berbahasa diperoleh informasi bahwa pada dasarnya pendekatan ini dalam pengajaran membaca permulaan menggunakan bahasa anak sebagai sumber pengajaran serta mengaitkan seluruh aspek kebahasaan dalam membaca Pengertian ini dapat disimpulkan dari pendapat Farr dan Roser (1979:99) LEA is the transcribing of children's oral language for the purpose of helping them to read. Sedangkan menurut May (1986:228-247) LEA is the use of a child's own language to teach him how to read, dan menurut Olson \&Dillner (1982:175) LEA is an approach to teaching reading which unifies all the language arts and puts the primary emphasis on total communication.
Berdasarkan pada tinjauan pengertian

Pendekatan

Pengalaman Berbahasa seperti yang telah diuraikan, maka dapat disimpulkan bahwa Pendekatan Pengalaman Berbahasa adalah suatu pendekatan pengajaran membaca permulaan yang menekankan pada peranan pengalaman anak sebagai bahan pengajaran. Pengalaman dalam hal ini sangat penting karena bermuara pada pengalaman inilah seseorang akan memiliki konsep yang nantinya akan dilahirkan dalam bentuk bahasa. Jadi, bahasa yang digunakan oleh seseorang semenjak ia masih anak- anak hingga usia lanjut merupakan pengalaman dan kebutuhan orang tersebut untuk berkomunikasi dan berinteraksi dengan lingkungannya.

Oleh karena itu tepat sekali apabila pendekatan pengalaman berbahasa digunakan sebagai pendekatan dalam pengajaran remedial membaca permulaan karena biasanya mempelajari sesuatu yang berasal dari pengalaman sendiri akan lebih mudah dan menarik serta lebih tertanam dalam pikiran. 
Dalam Pendekatan

Pengalaman Berbahasa ini, membaca menduduki tempat yang sama pentingnya dengan keterampilanketerampilan berbahasa lainnya, yakni untuk membentuk pondasi atau dasar pertukarah ide dan informasi. Adapun prinsip dasar Pendekatan Pengalaman Berbahasa ini antara lain: 1) pengajaran yang balk dimulai dengan apa yang diketahui oleh anak, maksudnya bahasa lisan yang diungkapkan anak merupakan rekaman yang sangat balk mengenai masa lalu anak; 2) pengajaran diarahkan pada pengajaran secara individu, karena pengajaran didasarkan pada minat dan kebutuhan anak, dengan pengajaran seperti ini anak dapat berkembang sesuai dengan kemampuannya, minat anak akan membawa dia ke tingkat kreativitas yang diingini; 3) keterampilan-keterampilan diperkenalkan bila diperlukan, dalam hal ini pengembangan keterampilan dilakukan dalam konteks yang bermakna melalui Pendekatan Pengalaman Berbahasa, penekanannya adalah reasoning dan pemanfaatan keterampilan, bukan keterampilan menghafal; 4) membaca dianggap sebagai satu bagian dari proses komunikasi, yang terpenting dalam pendekatan ini yaitu kaftan antara 'kata' lisan dengan bentuk grafiknya. Dalam membaca permulaan, guru menuliskan kata maupun cerita yang diungkapkan secara langsung oleh anak. Dengan cara ini anak akan mengerti dengan mudah bahwa membaca sebagai suatu metode berkomunikasi.

\section{b. Prosedur \\ Pendekatan}

\section{Pengalaman Berbahasa}

Sebelum diuraikan prosedur penggunaan Pendekatan Pengalaman Berbahasa dalam pengajaran membaca permulaan, akan dikemukakan konsep yang terkandung di dalam pendekatan ini, yakni bahwa dalam proses belajar membaca dengan pendekatan bahasa, anak berpartisipasi dalam pengalaman bersama, misalnya melihat gambar, mengamati objek-objek tertentu maupun rekreasi di luar rumah pada waktu-waktu tertentu. Pengalaman ini diungkapkan atau didiktekan di dalam kelas. Deskripsi dari pengalaman tersebut dituliskan oleh guru, kemudian cerita atau narasi yang diperoleh 
Edutech, Tahun 13, Vol.1, No.3, Oktober 2014

tersebut dibaca dengan bersuara oleh guru dan anak menirukan. Selanjutnya, anak membaca kembali cerita tersebut secara langsung dan mengulanginya beberapa kali. Akhirnya, anak memperoleh dan menyimpan lembaran cerita atau narasi yang telah ditulis oleh guru.

\section{SIMPULAN}

Prosedur penerapan Pendekatan Pengalaman Berbahasa dalam pengajaran membaca permulaan adalah sebagai berikut ini.

1. Langkah pertama, yaitu mengidentifikasi kemudahan bahasa, minat dan latar belakang pengalaman anak. Langkah ini bisa dilakukan dengan mengadakan percakapan ringan dengan anak mengenai halhal yang menarik bagi anak untuk dibicarakan pada waktu itu. Pada langkah pertama ini, peneliti menjajagi minat anak ada hari itu. Minat yang dimaksudkan adalah minat anak terhadap topik yang akan dibicarakan yang diusahakan berasal dari pengalaman anak itu sendiri. Langkah ini kurang lebih akan memakan waktu 5-10 menit.

2. Langkah kedua, yaitu merencanakan, mendiskusikan pengalaman anak atau topik yang telah dipilih oleh anak. Langkah ini dimaksudkan untuk mendata hal-hal apa yang menarik untuk diceritakan mengen'ai topik yang dipilih. Langkah ini sangat membantu kelancaran anak di dalam mengungkapkan pengalamannya. Pada langkah kedua ini, peneliti mendiskusikan minat dan pengalaman anak sehingga peneliti menemukan kata-kata yang menarik untuk dijadikan materi pembelajaran membaca. Langkah ini kurang lebih akan memakan waktu 10-15 menit.

3. Langkah ketiga, yaitu melakukan pencatatan terhadap ucapan lisan yang disampaikan oleh anak.

Pada langkah ketiga ini, peneliti yang menuliskan ucapan lisan tersebut pada papan tulis atau kertas karton. Hal penting yang harus diperhatikan dalam langkah ini adalah anak harus selalu memperhatikan apa yang dilakukan peneliti. Oleh karena itu saat menuliskan ucapan lisan anak, peneliti menuliskannya secara perlahan-lahan sambil membacanya dengan bersuara.

4. Langkah keempat, dalam penerapan Pendekatan Pengalaman Berbahasa untuk pengajaran membaca permulaan adalah mengembangkan sistem pengelolaan untuk 
Edutech, Tahun 13, Vol.1, No.3, Oktober 2014

memberikan keterampilan sesuai dengan kebutuhan anak. Pada Iangkah terakhir ini, peneliti membacakan ucapan Iisan anak yang ditulis pada Iangkah sebelumnya serta menggunakannya untuk mengajarkan proses membaca kepada anak. Peneliti membaca tulisan yang ada pada papan tulis secara berulang-ulang dan kemudian anak mengikutinya. Langkah ini kurang Iebih akan memakan waktu 10 menit.

\section{DAFTAR PUSTAKA}

Damaianti, V.S. (2001). Strategi Volisional Melalui Dramatisasi dalam Bidang Pendidikan Membaca (Disertasi). Bandung: PPS UPI.

Depdikbud. (1996). Kamus Besar Bahasa Indonesia. Jakarta: Balai Pustaka.

Devine. (1989). Teaching Reading in Elementary School from Theory to Practice.

Erhamwilda. (1997). Pengembangan Model Bimbingan Membaca Permulaan. Bandung: PPS UPI.

Farr, R. Dan Nancy R. (1979). Teaching A Child to Read. Harcourt Brace Jovannovich.

Harjasujana, A.S. (1988). Nusantara yang Literat: Secercah Saran terhadap Upaya Peningkatan Mutu Pendidikan di Indonesia. Pidato
Pengukuhan Guru Besar FPBS IKIP Bandung.

Harjasujana, AS dan Vismaia S.D. (2003). Membaca dalam Teori dan Praktik. Bandung: Mutiara.

Harjanatawiyoga, S dan M.I.F, Baihaqi. (1992). Pengajaran Remedi (Remedi Bahasa dan Matematika). Bandung: PLB IKIP.

Makmun, A.S. (1986). Psikologi Kependidikan. Bandung: IKIP.

Nurjanah, N. (1999). Perbandingan Keefektifan Metode Abjad, Global, SAS dalam Proses Belajar Mengajar Membaca Permulaan di Sekolah Dasar. Bandung: PPS UPI.

Rosidi, A. (1983). Pembinaan Minat Baca Bahasa dan Sastra (Kumpulan Karangan). Surabaya: Bina Ilmu.

Rusyana, Yus. (1984). Bahasa dan Sastra dalam Gamitan Pendidikan. Bandung: CV. Diponegoro.

Sudjana, N. (1988). Dasar-dasar Proses Belajar Mengajar. Bandung: Sinar Baru.

Tarigan, H.G. (1984). Membaca sebagai Suatu Keterampilan Berbahasa. Bandung: Angkasa. 